Daniel Kurniawan Harianto, Wulan Purnama Sari: Analisis Komunikasi Interpersonal Anak dan Orangtua Yang Berbeda Agama

\title{
Komunikasi Interpersonal Anak dan Orangtua Yang Berbeda
}

\author{
Agama \\ Daniel Kurniawan Harijanto, Wulan Purnama Sari \\ kurniawanhdaniel@gmail.com,wulanp@fikom.untar.ac.id
}

Fakultas Ilmu Komunikasi Universitas Tarumanagara

\begin{abstract}
Family is one of the important inner-structure institutions along with community and religion. Family is classified as a formal-primary social group. Each social group has perspectives which are determined by culture. Religion is one of culture's elements. Different religions have differences in the inherited messages and thing $(s)$ to believe. Interpersonal communication in a family with different religions between individuals becomes important. This research aims to know the interpersonal communication between a son/daughter and his/her parents whose parents have different religions. The theories used are attraction theory, family's form, social penetration, characteristics of relationship and communication patterns in a family. Researchers use intrinsic case study methods for this research. This research's content shows that religious differences between father and mother is not always a barrier for communication between family members. Similarities in passion, sex and religion can cause attraction in communication between family members. Openness cannot warrant that penetration reaches deep and personal conversations, but openness can determine the discussion result's form between discussing individuals.
\end{abstract}

Keywords: case study, family, interpersonal communication; religion differences.

\begin{abstract}
Abstrak
Keluarga menjadi salah satu institusi inner-structure yang penting bagi manusia bersama dengan komunitas dan agama. Keluarga termasuk ke dalam kelompok sosial formal-primer. Setiap kelompok sosial memiliki cara pandang yang ditentukan oleh budaya. Agama menjadi salah satu elemen budaya. Agama yang berbeda memiliki perbedaan dalam pesan yang bertahan dan apa yang harus dipercayai. Komunikasi interpersonal dalam keluarga dengan perbedaan agama antar individu menjadi penting. Penelitian ini bertujuan mengetahui komunikasi interpersonal antara anak dengan orangtuanya dimana terdapat perbedaan agama antara ayah dengan ibunya. Teori yang digunakan antara lain teori tentang atraksi, bentuk keluarga, penetrasi sosial, karakteristik-karakteristik hubungan dan pola komunikasi dalam keluarga. Peneliti menggunakan metode studi kasus intrinsik. Penelitian ini menunjukkan bahwa perbedaan agama antara ayah dan ibu tidak selalu menjadi penghambat dalam komunikasi antarpribadi antar anggota keluarga. Kesamaan minat, jenis kelamin dan agama dapat menimbulkan ketertarikan dalam komunikasi antar anggota keluarga. Keterbukaan tidak menjamin penetrasi mencapai percakapan yang dalam dan pribadi. Namun demikian, keterbukaan dapat menentukan bentuk hasil diskusi antar individu yang berdiskusi.
\end{abstract}

Kata Kunci: Keluarga; komunikasi interpersonal; perbedaan agama; studi kasus

\section{Pendahuluan}

Keluarga merupakan salah satu dari institusi struktur-dalam (inner-structure) yang penting bagi manusia. Menurut Samovar, Porter dan McDaniel, keluarga menjadi salah satu institusi yang penting bagi penanaman apa yang harus diperjuangkan. Selain 
itu, keluarga juga menjadi pembawa apa yang paling dipercayai dalam suatu budaya, misalnya sumber kebahagiaan. Selain itu juga menjadi pembawa pesan yang bertahan karena diajarkan kepada generasi selanjutnya. Keluarga merupakan transmitter utama pengetahuan, nilai, perilaku, peranan dan kebiasaan dari generasi ke generasi. Menurut DeGenova dan Rice, perilaku dan contoh yang dilihat seorang anak membentuk kepribadian, menanamkan pola pikir serta cara bertingkah laku seorang anak sehingga menjadi kebiasaan. Menurut Samovar, agama memiliki ikatan dengan persepsi dan perilaku.

Keluarga termasuk ke dalam kelompok sosial formal-primer (Bungin, 2017). Hal tersebut disebabkan bahwa keluarga inti memiliki hubungan antaranggota yang intensif. Selain itu, menurut Kraft (dalam Samovar et al, 2010) setiap kelompok sosial memiliki cara pandang. Apabila dikaitkan dengan agama, agama sebagai cara pandang erat kaitannya dengan kepercayaan dan praktik agama. Agama sendiri merupakan salah satu dari elemen budaya, sebagaimana dipaparkan oleh Samovar.

Menurut Joseph A. DeVito (2016), terdapat beberapa faktor yang menentukan ketertarikan dalam komunikasi interpersonal, yaitu similarity, proximity dan reinforcement. Selain itu, berdasarkan tingkat percakapan dan konformitas DeVito mengemukakan empat tipe keluarga, yaitu laizzes-faire, pluralistik, protektif dan konsensual. Dalam suatu hubungan, kepercayaan dapat berarti pemberi pesan percaya ia tidak akan mendapatkan ancaman dari hubungan tersebut. Menurut DeVito (2016) dalam keluarga terdapat empat pola komunikasi, yaitu pola kesamaan, pembagian seimbang, pembagian tidak seimbang dan monopoli.

Penelitian Setiawan dan Azeharie (2017) tentang studi komunikasi antarpribadi anak dengan orangtua tiri diketahui bahwa anak yang mengenal calon orang tua tiri sebelum menikah dengan orangtua kandungnya memiliki hubungan relatif lebih baik dibandingkan dengan anak yang tidak mengenal calon orang tua tirinya sebelum menikah. Komunikasi antarpribadi yang terjadi juga tergantung dari karakter anak dan orangtua tiri masing-masing.

Penelitian Trianasari dan Amir (2013) tentang pola komunikasi dalam pola asuh pada orangtua berbeda agama menunjukkan bahwa ada orangtua dengan perbedaan agama yang memiliki pola komunikasi otoriter dan ada pula yang menunjukkan pola komunikasi demokratis. Penelitian ini dilakukan pada pasangan berbeda agama yang memiliki lebih dari satu anak. Pola komunikasi antara orangtua tiri dengan anak ditentukan oleh komunikasi yang efektif.

Berbeda dengan kedua penelitian sebelumnya, penelitian Azeharie, Paramita dan Sari (2019) tentang budaya nonmaterial warga Jaton menunjukkan bahwa keharmonisan dan kerukunan keluarga Kristen dan keluarga Islam tetap terjaga. Hal tersebut ditunjukkan dengan keluarga Islam yang mengunjungi keluarga Kristen pada saat Natal. Demikian pula sebaliknya, keluarga Kristen mengunjungi keluarga Islam pada waktu Lebaran.

Berdasarkan paparan di atas penulis melakukan penelitian dengan rumusan masalah bagaimana komunikasi interpersonal antara anak dengan orangtua dimana terdapat perbedaan agama antara ayah dan ibu? Adapun tujuan penelitian ini adalah mengetahui komunikasi interpersonal yang terjadi antara anak dengan orangtuanya dimana terdapat perbedaan agama antara ayah dengan ibunya. 
Daniel Kurniawan Harianto, Wulan Purnama Sari: Analisis Komunikasi Interpersonal Anak dan Orangtua Yang Berbeda Agama

\section{Metode Penelitian}

Dalam penelitian ini, peneliti menggunakan pendekatan kualitatif dengan metode studi kasus. Menurut Gunawan (2017), melalui pendekatan ini akan terungkap gambaran tentang aktualisasi, realitas sosial dan persepsi sasaran penelitian. Peneliti merasa perlu menggunakan pendekatan kualitatif karena tidak semua nilai, perilaku dan interaksi dapat diteliti dengan pendekatan kuantitatif. Hal tersebut disebabkan bahwa persepsi seseorang sangat tergantung pada nilai-nilai, budaya dan pengalaman dari individu yang diteliti.

Pada studi kasus intrinsik, peneliti dapat menemukan pengetahuan tentang kekhususan dan keunikan dari kasus-kasus yang diteliti. Peneliti melakukan wawancara mendalam pada dua orang anak beserta orangtua mereka di mana terdapat perbedaan agama antara ayah dengan ibunya. Dalam penelitian ini, peneliti menggunakan teknik analisis data yang terdiri dari tiga tahap, yaitu reduksi data, paparan data dan penarikan kesimpulan/verifikasi.

\section{Hasil Penemuan dan Diskusi}

Peneliti menemukan bahwa faktor atraksi tidak hanya ditentukan oleh kedekatan secara fisik (proksimitas), namun juga kesamaan minat, jenis kelamin, kedekatan emosional dan adanya reward yang diterima dari suatu perlakuan. Reward dalam pengertian ini adalah hal yang dapat meningkatkan harga diri seseorang (Tatang, 2016). Kemiripan yang terdapat pada informan pertama dengan ayahnya adalah kesamaan minat dalam bidang politik. Kedekatan emosional terjadi saat ayah dari informan pertama mendekatkan diri pada informan pertama pada waktu informan pertama memasuki perkuliahan. Pendekatan tersebut direspon dengan keterbukaan dari informan pertama yang menyebabkan terjadinya penetrasi sebagaimana dikatakan oleh Bungin (2017). Kedekatan emosional itulah yang menyebabkan informan pertama senang berdiskusi dengan ayahnya. Pada sisi lain, kemiripan yang terdapat pada informan pertama dengan ibunya antara lain kesamaan dalam jenis kelamin dan tingkat kerohanian. Hal tersebut disebabkan bahwa informan pertama dan ibunya sama-sama melayani di gereja yang sama.

Menurut informan pertama, dirinya lebih nyaman berdiskusi dengan ibunya. Informan pertama menganggap ibunya lebih mengerti perasaan perempuan. Selain itu, ibu dari informan pertama juga sering memberikan kesaksian hidup bersama Tuhan pada saat infoman pertama bercerita tentang kesehariannya. Ibunya juga merasa bahwa keterbukaan anaknya sangat menguntungkan. Beliau juga tidak merasa takut atau terancam pada waktu berdiskusi dengan informan pertama karena hal tersebut menyangkut kebaikan anaknya di masa depan.

Informan kedua lebih sering berkomunikasi dengan ibu daripada ayah. Menurut informan kedua, ayahnya adalah sosok pendiam. Obrolan dengan ayahnya berpusat pada pekerjaan dari informan kedua. Meskipun demikian, hubungan informan kedua dengan ayahnya tetap baik. Berbeda dengan ayahnya, ibu dari informan kedua sering mengobrol dengan informan kedua saat informan kedua berada di rumah. Obrolan yang terjadi biasanya berkisar pada pekerjaan informan kedua, nasihat beliau tentang keimanan juga tentang pergaulan. Menurut ibunya, informan kedua adalah seorang penurut. Pada sisi lain, informan kedua juga merasa nyaman pada waktu berdiskusi dengan orangtuanya. Informan kedua percaya ibunya tidak memberikan ancaman terhadap dirinya, sesuai pendapat Tubbs (2012) tentang 
kepercayaan. "Lebih ke santai sih, kalo sama orang tuaku", kata informan kedua. Menurut informan kedua, ibunya memiliki pikiran yang sama dengan dirinya. Informan kedua juga mendapatkan ganjaran (reward) berupa rasa aman pada waktu berdiskusi dengan ibunya.

Pada keluarga informan ketiga, faktor yang menyebabkan atraksi antara informan ketiga dengan ayahnya adalah adanya kesamaan minat pada topik-topik berita. Informan ketiga setiap hari berkomunikasi dengan ayahnya, baik melalui WhatsApp maupun tatap muka. Percakapan yang terjadi di rumah biasanya terkait dengan berita-berita politik (apabila informan ketiga pulang cepat) atau perkuliahan informan ketiga, sedangkan percakapan sehari-hari seperti "makan di mana?" atau "lagi di mana?" dilangsungkan melalui WhatsApp. Kendati demikian, informan ketiga jarang berdiskusi dengan ayahnya. Hal tersebut disebabkan ayahnya sering berada di luar kota dan juga berwatak keras. Pada sisi lain, ayahnya merasa nyaman pada waktu berdiskusi dengan anaknya. Berbeda dengan ayahnya, faktor penyebab ketertarikan pada komunikasi antara informan ketiga dengan ibunya adalah adanya pikiran yang terbuka pada ibunya. Penetrasi terjadi pada diskusi informan ketiga dengan ibunya karena informan ketiga merasa senang karena pikiran yang terbuka tersebut, sesuai dengan pendapat Bungin (2017).

Berdasarkan pendapat DeVito (2016) tentang empat tipologi keluarga, keluarga informan pertama memiliki orientasi percakapan yang tinggi, demikian pula dengan keluarga informan kedua. Pada keluarga informan ketiga, tingkat percakapan yang tinggi juga nampak terutama pada komunikasi antara informan ketiga dengan ibunya.

Pada diskusi dengan orangtuanya, hasil diskusi informan pertama dengan orangtuanya biasanya berupa kesepakatan bersama. Pada saat hendak mengambil keputusan yang penting, hasil diskusi antara informan pertama dengan orangtuanya berbentuk kesepakatan bersama. Perbedaannya, ayah dari informan pertama memberi kebebasan pada informan pertama untuk memilih, sedangkan diskusi informan pertama dengan ibunya menghasilkan kesepakatan walaupun dapat saja disertai adu argumen lebih dahulu. Informan pertama mengatakan bahwa ayahnya adalah sosok yang paling dominan dibandingkan dirinya dan ibunya. Hal tersebut juga dikonfirmasi oleh ibu dan ayah dari informan pertama sendiri. Mereka berpendapat bahwa dominasi tersebut disebabkan oleh posisi ayah dari informan pertama sebagai kepala keluarga. dalam pengambilan keputusan tentang rumah tangga, ayahnyalah yang berperan mengambil keputusan.

Pada keluarga informan kedua, informan kedua jarang berdiskusi dengan ayahnya. Meskipun demikian, informan kedua menyatakan bahwa hasil diskusi dirinya dengan ayahnya biasanya berbentuk kesepakatan bersama. Informan kedua lebih mencari ibunya untuk meminta pendapat atau saran. Menurut ibunya, pada waktu mencari saran, informan kedua akan mengikuti saran beliau, sedangkan hasil diskusi tentang usaha atau kegiatan keluarga berbentuk kesepakatan bersama. Menurut informan kedua, ibunya adalah seorang yang paling dominan dibandingkan dirinya dan ayahnya. Hal tersebut disebabkan informan kedua lebih dekat dan lebih terbuka pada ibunya.

Pada keluarga informan ketiga, bentuk hasil diskusi yang biasanya terjadi antara informan ketiga dengan ayahnya lebih banyak mengikuti kemauan ayah. Hal ini karena ayahnya adalah orang yang berwatak keras. Berbeda dengan putrinya, menurut ayah dari informan ketiga, hasil diskusi dengan putrinya merupakan kesepakatan bersama. Menurut informan ketiga, ayahnya adalah yang paling dominan 
Daniel Kurniawan Harianto, Wulan Purnama Sari: Analisis Komunikasi Interpersonal Anak dan Orangtua Yang Berbeda Agama

dibandingkan dirinya dan ibunya. Hal ini karena ayahnya memiliki watak keras, sedangkan ayahnya mengatakan bahwa tidak ada yang lebih dominan. Pada sisi lain, hasil diskusi informan ketiga dengan ibunya kebanyakan berbentuk kesepakatan bersama.

Berdasarkan hasil diskusi para informan dengan orangtuanya dapat dikatakan bahwa pada informan pertama, keluarga memiliki tingkat percakapan dan konformitas yang tinggi, demikian pula dengan keluarga dari informan kedua. Konformitas yang tinggi pada informan pertama disebabkan oleh posisi ayah informan pertama sebagai kepala keluarga. Pola komunikasi yang ada pada keluarga informan pertama merupakan pola komunikasi kesamaan. Keluarga dengan pola komunikasi kesamaan secara sama rata terbuka terhadap ide, pendapat dan kepercayaan dari orang lain. Komunikasi yang terjadi dalam keluarga ini terbuka, jujur, langsung dan bebas dari permainan kekuasaan (power plays). Meskipun demikian, terdapat ciri dari pola komunikasi pembagian seimbang (balanced split pattern), misalnya pada waktu informan pertama meminta saran pada ibunya. Hal tersebut disebabkan bahwa hasil diskusi bergantung pada topiknya.

Pada keluarga dari informan kedua, tingkat percakapan dan konformitas yang tinggi menyebabkan keluarga dari informan kedua termasuk keluarga konsensual meskipun terdapat pola komunikasi tidak seimbang karena dominasi ibunya. Selain itu, terdapat faktor ketertarikan pada informan kedua dengan ibunya, yakni adanya kesamaan pikiran. Informan kedua juga merasa tidak akan mendapatkan ancaman dari ibunya. Berbeda dengan keluarga informan kedua, keluarga informan ketiga menunjukkan tingkat kepatuhan yang tinggi tanpa menutup kesempatan berdialog. Pada sisi lain, menurut Bungin (2017) orang menggunakan persepsinya untuk menilai keseimbangan cost and rewards yang ia lakukan dan terima. Informan ketiga mempersepsikan ayahnya sebagai orang yang berwatak keras sehingga ia memasang prejudice sehingga lebih cenderung mengiyakan ayahnya pada saat ayahnya berpendapat dan informan ketiga sedang tidak ingin beradu pendapat dengan ayahnya. Pada sisi lain, pada waktu tersebut ayahnya mendapatkan respons mendukung, sesuai pernyataan Tubbs (2012) tentang respons yang mendukung. Pola komunikasi yang terjadi antara informan ketiga dengan ayahnya cenderung monopolistik. Berbeda dengan ayahnya, di antara informan ketiga dengan ibunya terdapat tingkat percakapan dan konformitas yang tinggi karena pikiran terbuka dari ibunya dan kepatuhan informan ketiga serta ibunya kepada kesepakatan yang terbentuk. Berdasarkan hal tersebut dan keterbukaan dalam interaksi informan ketiga dengan orang tuanya, dapat dikatakan bahwa keluarga informan ketiga cenderung monopolistik.

Penetrasi terjadi pada saat kesukaan dua orang bertemu. Selain itu, menurut Bungin (2017), penetrasi terjadi dari komunikasi basa-basi lalu masuk ke pada percakapan yang mendalam dan bersifat pribadi. Hal ini yang terjadi pada informan pertama dengan ayahnya ketika sedang mengobrol tentang perpolitikan, juga tentang keseharian masing-masing. Pada awal percakapan dengan ayahnya, percakapan terjadi mengalir. Informan pertama sering mengobrol tentang perkuliahan dengan ayahnya pada saat makan berdua. Percakapan informan pertama dengan ayahnya menjadi panjang pada waktu membahas tentang perpolitikan yang merupakan topik kesukaan mereka. Percakapan mereka juga menjadi panjang pada waktu membahas tentang keseharian. Dalam percakapan dengan ibunya, informan pertama cenderung to the point dalam bercakap dengan ibunya, sedangkan ibunya menganggap hal tersebut sebagai awal percakapan dengan putrinya. Pada percakapan informan pertama dengan ibunya, terdapat respons mendukung yang didapat informan pertama dari ibunya, 
misalnya pada saat ibunya memberikan kesaksian ketika informan pertama membagikan pengalamannya dalam pengerjaan skripsi. Kendati demikian, informan pertama dapat membahas bermacam-macam hal dengan ibunya pada waktu mengobrol panjang.

Pada komunikasi antara informan kedua dengan ibunya, penetrasi terjadi terbalik. Percakapan informan kedua dengan ibunya terjadi dari inti pembicaraan, mengobrol dengan intens lalu masuk ke dalam candaan atau obrolan ringan. Selain itu, terkait kenyamanan informan kedua, apa yang terjadi pada informan kedua sesuai pendapat Bungin (2017) bahwa orang melanjutkan hubungan ke arah yang lebih akrab dan dalam kalau mendapatkan kesenangan dan keuntungan. Hal tersebut (kenyamanan) terjadi pada diskusi antara informan kedua dengan orangtuanya. Meskipun demikian, kenyamanan informan kedua dan rasa percaya yang lebih kepada ibunya tampak pada intensitas obrolan informan kedua dengan ibunya juga curhat yang lebih banyak ia lakukan dengan ibunya.

Pada informan ketiga, penetrasi hanya sampai pada tingkat komunikasi basabasi dan baru mencapai komunikasi yang mendalam pada waktu membahas tentang berita atau apa yang tersebar di media sosial. Informan ketiga mengatakan bahwa dirinya bukan orang yang suka bercerita. Percakapan yang terjadi biasanya membahas seputar perkuliahan atau udah makan apa belum. Pembahasan personal jarang terjadi, malah lebih menjurus pada perkuliahan atau topik-topik berita yang merupakan topik kesukaan informan ketiga dan kedua orangtuanya. Ayah informan ketiga juga mengatakan bahwa informan ketiga jarang bercerita. Beliau juga menanyakan pertanyaan sehari-hari seperti "udah makan belom?" Menurut beliau, perbincangan personal dengan putrinya lebih banyak dimulai dirinya.

Berdasarkan hal-hal tersebut, kedalaman dan keluasan dari topik pembahasan dari informan pertama dengan ayahnya sangat besar, demikian pula dengan ibunya. Informan kedua lebih jarang mengobrol dengan ayahnya dibandingkan dengan ibunya sehingga keluasan topik pembicaraan informan kedua dengan ayahnya kurang dibandingkan dengan ibunya. Meskipun demikian, aspek keluasan lebih menonjol dalam percakapan informal kedua dengan ayahnya karena ayahnya adalah orang yang suka bercanda. Kedalaman dalam percakapan informan kedua dengan ibunya lebih menonjol dibandingkan keluasannya.

Keterbukaan yang terjadi pada informan pertama ditunjukkan dengan bercerita apa adanya dengan orangtuanya, demikian pula dengan ayah dan ibunya terhadap dirinya. Keterbukaan tersebut dapat dikatakan merupakan hasil dari penetrasi terhadap informan pertama, sesuai pernyataan Bungin (2017). Informan kedua tidak terlalu terbuka dengan ayahnya karena menurutnya tidak ada yang ia anggap serius untuk diperbincangkan dengan ayahnya. Sebaliknya, ia terbuka dengan ibunya dan ditunjukkan dengan curhat dan membahas hal-hal personal. Ibunya juga mengatakan bahwa beliau sangat terbuka dengan anak-anaknya dan mendidik anak-anaknya untuk terbuka dalam sharing kepada ibunya tentang apapun. Berbeda dengan informan kedua, informan ketiga tidak terlalu terbuka pada waktu membahas hal-hal serius karena informan ketiga bukan orang yang suka bercerita. Berbeda dengan informan ketiga, ayahnya terbuka pada waktu membahas hal-hal serius. Bagi ayah dari informan ketiga, beliau terbuka karena beliau beranggapan bahwa keluarga adalah tempatnya untuk bercerita. Beliau hanya tidak menceritakan semua hal yang bersifat permasalahan keluarga agar informan ketiga tidak kepikiran. Berdasarkan keterbukaan-keterbukaan tersebut, dengan melihat pula hasil diskusi informan pertama dengan orangtuanya dan kenyamanan masing-masing pribadi (informan pertama dan 
Daniel Kurniawan Harianto, Wulan Purnama Sari: Analisis Komunikasi Interpersonal Anak dan Orangtua Yang Berbeda Agama

orang tuanya), dapat terlihat bahwa kepercayaan seperti yang dimaksud Tubbs (2012) tampak pada keluarga informan pertama. Bagi ibu informan pertama, tidak ada rasa terancam pada waktu berdiskusi dengan putrinya. Kepercayaan yang sama juga terlihat pada hubungan informan kedua dengan ibunya dan terlihat lebih besar dibandingkan dengan ayahnya. Pada informan ketiga, kepercayaan dengan ayahnya dapat dikatakan tidak muncul saat informan ketiga sedang tidak ingin beradu pendapat dengan ayahnya. Kepercayaan tersebut muncul pada saat membahas hal-hal lain. Kepercayaannya dapat hilang atau muncul pada situasi tertentu.

Para informan dengan orangtua mereka sudah saling mengenal nada bicara masing-masing sehingga tidak mengalami gangguan semantik maupun teknis dalam komunikasi. Meskipun demikian, terdapat kemungkinan gangguan teknis pada ibu dari informan pertama karena nada bicara beliau mengikuti informan pertama seandainya informan pertama tanpa sengaja bersuara tinggi saat bercanda atau mengobrol santai. Nada bicara para informan cenderung santai pada saat mengobrol tentang hal-hal santai, menggunakan nada bicara biasa pada saat mengobrol serius dan meninggi namun segera menurun kembali pada saat terjadi konflik antara para informan dengan orang tua mereka masing-masing. Terdapat perbedaan pada informan kedua dimana ibunya mengatakan bahwa nada bicara informan kedua pada waktu mengobrol hal-hal serius adalah nada bicara yang tegas. Adapun para orangtua juga menggunakan nada bicara yang berbeda pada waktu mengobrol serius dan ada peningkatan nada suara pada waktu terjadi konflik, kecuali pada ayah dari informan kedua yang lebih memilih diam daripada beradu pendapat.

Berdasarkan hal tersebut, dapat dikatakan bahwa kepemilikan bersama atas informasi tentang kerohanian antara informan pertama dengan ibunya lebih luas dan lebih dalam dibandingkan dengan ayahnya. Demikian pula dengan informan kedua yang memiliki keluasan dan kedalaman yang lebih besar pada ibunya. Hal tersebut disebabkan informan pertama dan kedua lebih sering berbagi kesaksian dengan ibu mereka dibandingkan ayah mereka. Selain itu, informan pertama juga mengobrol tentang khotbah dari sebuah ibadah juga pengkhotbah yang membawakannya. Meskipun demikian, informan pertama tetap memberikan kesaksian dengan ayahnya. Informan kedua juga menyampaikan nilai-nilai kekristenan pada ayahnya yang beragama Islam, sedangkan ayahnya tidak pernah membagikan tentang kerohanian dari agamanya. Pada informan ketiga dan orang tuanya, kepemilikan bersama atas informasi tentang kerohanian atau keagamaan sangat rendah karena mereka beranggapan untuk saling menghargai kepercayaan masing-masing. Ayah dari informan ketiga beragama Budha sedangkan ibunya adalah seorang muslimah yang aktif dan informan ketiga sendiri aktif melayani di gereja Kristen yang sama dengan informan pertama dan kedua. Meskipun demikian, ayah dari informan ketiga pernah mengobrol tentang penggusuran vihara yang muncul di berita dengan putrinya.

\section{Simpulan}

Kedekatan fisik tidak dapat menjadi satu-satunya faktor ketertarikan pada komunikasi anak dengan orangtua. Terdapat faktor-faktor lain yang turut bermain seperti kesamaan minat, jenis kelamin atau agama juga rasa aman. Meskipun demikian, agama tidak selalu menjadi penghalang komunikasi orangtua dan anak. Kedekatan juga dapat disebabkan oleh complementary, seperti orang yang menyenangi seseorang yang patuh pada otoritas. Pada keluarga yang terbiasa membahas hal-hal rohani, pembahasan hal-hal rohani menonjol. 
Keterbukaan tidak menjamin penetrasi akan mencapai percakapan mendalam dan pribadi. Apabila salah satu tidak terbuka, maka akan sulit mencapai ranah pribadi komunikan. Keterbukaan kedua orang tersebut dapat mempengaruhi hasil diskusi.

\section{Ucapan Terima Kasih}

Penulis mengucapkan terima kasih kepada semua pihak yang telah turut berpartisipasi dalam penelitian ini, khususnya para narasumber dan rekan-rekan penulis yang telah menyemangati penulis dalam penelitian ini.

\section{Daftar Pustaka}

Azeharie, Suzy, Paramita, Sinta dan Sari, Wulan Purnama. (2019). Studi Budaya Nonmaterial Warga Jaton. Jurnal ASPIKOM, 3 (6), 1153-1162. Januari 08, 2020 . Terarsip di http://jurnalaspikom.org/index.php/aspikom/article/view/279

Bungin, B. (2017). Sosiologi Komunikasi: Teori, Paradigma dan Diskursus Teori Komunikasi di Masyarakat. Jakarta: Prenada Media Group

DeVito, J. A. (2016). The Interpersonal Communication Book (Fifteenth edition). England: Pearson Education Limited

Gunawan, I. (2017). Metode Penelitian Kualitatif: Teori \& Praktik. Jakarta: PT Bumi Aksara

Morissan. (2010). Psikologi Komunikasi. Bogor: Penerbit Ghalia Indonesia

Samovar, L. A., Porter, R. E., McDaniel, E. R. (2010). Komunikasi Lintas Budaya (Edisi ketujuh) (Margaretha Sidabalok, Penerjemah). Jakarta: Penerbit Salemba Humanika

S., Tatang. (2016). Dinamika Komunikasi. Bandung: CV Pustaka Setia

Sarwono, S. W. (2015). Psikologi Lintas Budaya. Jakarta: Rajawali Pers

Setiawan, Chaterine dan Azeharie, Suzy. (2017). Studi Komunikasi Antarpribadi Anak Dengan Orang Tua Tiri. Jurnal Komunikasi, 9 (1), 74-80. Desember 30, 2019. Terarsip di https://journal.untar.ac.id/index.php/komunikasi/article/view/79

Trianasari dan Amir, Andi Subhan. (2013). Pola Komunikasi Antarpribadi Dalam Pengasuhan Anak: Kasus Orang Tua Beda Agama. Jurnal Komunikasi KAREBA, 2 (1), 12-29. Desember 30, 2019. Terarsip di http://journal.unhas.ac.id/index.php/kareba/article/view/345/0

Tubbs, S. L. dan Moss, S. (2012). Human Communication: Prinsip-prinsip Dasar (Deddy Mulyana dan Gembirasari, Penerjemah). Bandung: PT Remaja Rosdakarya 